\title{
Calcium sensor parameters and readout configurations for activity-dependent homeostatic regulation of pyloric network rhythms in the lobster stomatogastric ganglion Cengiz Günay* and Astrid A Prinz
}

\author{
Address: Biology Department, Emory University, Atlanta, GA 30033, USA \\ Email: Cengiz Günay* - cgunay@emory.edu \\ * Corresponding author
}

from Eighteenth Annual Computational Neuroscience Meeting: CNS*2009

Berlin, Germany. 18-23 July 2009

Published: 13 July 2009

BMC Neuroscience 2009, I0(Suppl I):O4 doi:I0.I I86/I47|-2202-I0-SI-O4

This abstract is available from: http://www.biomedcentral.com/I47I-2202/I0/SI/O4

(c) 2009 Günay and Prinz; licensee BioMed Central Ltd.

In central pattern generating (CPG) neural networks, activity-dependent homeostatic regulation (ADHR) has been proposed to explain the experimentally observed robust activity that persists in spite of constant molecular turnover and environmental changes. In the pyloric CPG network of the lobster stomatogastric ganglion (STG), ADHR is dependent on and correlated with levels of intracellular calcium, which acts as a second messenger that affects ion channel and synaptic properties of the cell. Previous studies showed that calcium sensors can be used to maintain stable activity levels in individual model neurons [1] and pyloric rhythms in one model network [2]. For regulation, these studies used deviations of the calcium current from a target value. However, they did not address the choice of sensor activation and inactivation variables, and the robustness of selected parameters and sensor configurations in the network. To address these issues, we developed a testbed that judges the quality of a sensor by using its readings to make a prediction about whether a network activity pattern is functional.

To make predictions, we used a classifier trained with sensor readings from a model pyloric network database [3]. Based on their selected activity characteristics being similar to biological data, $2 \%$ of these networks were labeled as functional. In each testbed with different sensor placements and parameters, the percentage of functional networks correctly predicted by the classifier is indicated with a success rate.
Directly using the average calcium concentration from the three model cells of the network resulted in a $52 \%$ prediction success if shuffled, establishing a control case, compared to $77 \%$ without shuffling. Using average calcium current instead of the concentration, we obtained a similar success $(77 \%)$, supporting the choice by earlier calcium sensor models $[1,2]$. We confirmed that the success rate increased by the addition of activation $(78 \%)$ and inactivation $(86 \%)$ variables in the averaged sensors, showing that the inactivation component is indispensable (see Figure 1). By testing all combinations of selected activation and inactivation parameters, we found their optimal values. It is biologically reasonable for the sensor minimal and maximal values to be involved in regulation and using them in addition to the sensor averages increased the success to $87 \%$. Finally, using the fast, slow and DC sensors proposed earlier [1] together in the same cell marginally increased the success further to $88 \%$. Taken together, our results suggest that activity sensing for ADHR of the pyloric network can potentially be achieved with relatively few, simple calcium sensors and that the properties of these sensors need not necessarily be adjusted to the particular role of each neuron in the network.

\section{Acknowledgments}

This work is supported by 1 R01 NS054911-01A1 from NINDS and a Career Award at the Scientific Interface from the Burroughs Wellcome Fund awarded to AAP. R. Hooper and K.R Hammett contributed to preliminary results. 

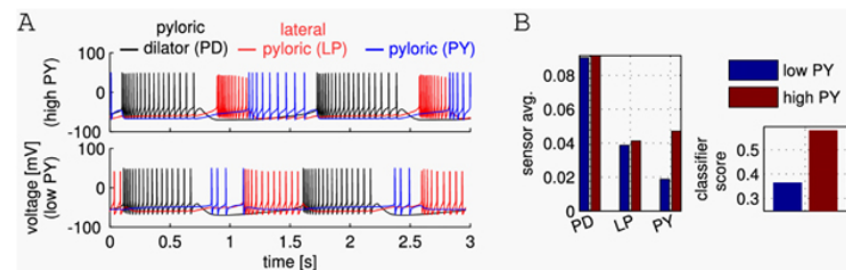

Figure I

A. Activity patterns of the three model cells for a functional (top) and a non-functional (bottom) network. B. Sensor averages (left) show low activity in the PY model cell, which reduces the classifier score (right) below the "functional threshold" of 0.5 to make a correct prediction.

\section{References}

I. Liu Z, Golowasch J, Marder E, Abbott LF: A model neuron with activity-dependent conductances regulated by multiple calcium sensors. J Neurosci 1998, 18:2309-2320.

2. Golowasch J, Casey M, Abbott LF, Marder E: Network stability from activity-dependent regulation of neuronal conductances. Neural Comput 1999, I I:

3. Prinz AA, Bucher D, Marder E: Similar network activity from disparate circuit parameters. Nature Neurosci 2004, 7:.
Publish with Bio Med Central and every scientist can read your work free of charge

"BioMed Central will be the most significant development for disseminating the results of biomedical research in our lifetime. "

Sir Paul Nurse, Cancer Research UK

Your research papers will be:

- available free of charge to the entire biomedical community

- peer reviewed and published immediately upon acceptance

- cited in PubMed and archived on PubMed Central

- yours - you keep the copyright 